\title{
LABORATORY EVALUATION OF THE EFFECT OF INSECTICIDES ON CHRYSOPERLA CARNEA (NEUROPTERA: CHRYSOPIDAE), FORFICULA AURICULARIA (DERMAPTERA: FORFICULIDAE), ADALIA BIPUNCTATA (COLEOPTERA: COCCINELLIDAE) AND HARMONIA AXYRIDIS (COLEOPTERA: COCCINELLIDAE)
}

\author{
Kamil Holý1 ${ }^{1}$ Jitka Stará ${ }^{1}$ \\ ${ }^{1}$ Crop Research Institute, Drnovská 507, Prague 6, Czech Republic \\ Link to this article: https://doi.org/10.11118/actaun202068030497 \\ Received: 12. 12. 2019, Accepted: 12. 5. 2020 \\ To cite this article: HOLÝ KAMIL, STARÁ JITKA. 2020. Laboratory Evaluation of the Effect of Insecticides \\ on Chrysoperla carnea (Neuroptera: Chrysopidae), Forficula auricularia (Dermaptera: Forficulidae), Adalia \\ bipunctata (Coleoptera: Coccinellidae) and Harmonia axyridis (Coleoptera: Coccinellidae). Acta Universitatis \\ Agriculturae et Silviculturae Mendelianae Brunensis, 68(3): 497-506.
}

\begin{abstract}
The effect of 8 biopesticides and 23 synthetic pesticides on the eggs and larvae of Chrysoperla carnea (Stephens, 1836), adults of Forficula auricularia Linnaeus, 1758, larvae of Adalia bipunctata (Linnaeus, 1758) and adults of Harmonia axyridis (Pallas, 1773) have been evaluated under laboratory conditions. All of the tested biopesticides were harmless (causing mortality $<30 \%$ ) or only slightly harmful (causing mortality 30-79\%) to the tested natural enemies. The tested synthetic fungicides were harmless or slightly harmful, with the exception of myclobutanil, which was moderately harmful (causing mortality 90-99\%) to A. bipunctata larvae. The tested synthetic insecticides were harmless or slightly harmful to $C$. carnea eggs and $F$. auricularia larvae. Various results were obtained for neonicotinoids ranging from the harmful effects (causing mortality > 99\%) of thiacloprid on A. bipunctata larvae and $H$. axyridis adults to the harmless effects of acetamiprid on $F$. auricularia adults and $C$. carnea eggs. Thiacloprid, dodine and chlorpyrifos-methyl had effects on the behaviour of $F$. auricularia adults. The results confirmed the selectivity of the tested biopesticides that had no negative effects on the tested natural enemies.
\end{abstract}

Keywords: Adalia bipunctata, Chrysoperla carnea, Forficula auricularia, Harmonia axyridis, pesticides, natural enemies, bioassay

\section{INTRODUCTION}

Predators and parasitoids generally contribute to the reduction in pest populations in agricultural crops. However, their ability to prevent fully and reliably pest damage is limited. Hence, finding a balance between the use of insecticides and the survival of natural enemies is one of the main priorities of integrated pest management (IPM). As apple and pear growers shift to selective control strategies for major arthropod pests, there is often a noticeable increase in the densities of natural enemies in their orchards (Epstein et al., 2000; Miliczky et al., 2000). The reduction in pesticide 
use and long-term mating disruption for Cydia pomonella (Linnaeus, 1758) led to an increased abundance of natural enemies and reduction in Cacopsylla pyricola (Förster, 1848) outbreaks (Amarasekare et al., 2017). In contrast, the repeated application of less selective insecticides can promote biological imbalances in ecosystems and can lead to the loss of IPM function (Meissle et al., 2010). There is good evidence that insecticides, especially those used for Cydia pomonella, elevated $C$. pyricola to key pest status by suppressing its natural enemies (Westigard, 1973). Gallardo et al. (2016) documented that a stepwise increase in natural enemy risk values increased the total pest management costs by $\$ 46 /$ ha and $\$ 44 /$ ha in natural enemy unfavourable apple and pear orchards, respectively.

The utilization of insecticides with few negative impacts on beneficial arthropods is necessary. Knowledge of the selectivity of insecticides allows us to adjust the choice of the insecticides used based on the presence of beneficial species and their sensitive developmental stages at the time of application.

To protect habitats in agricultural and surrounding areas, testing the side effects of pesticides on non-target organisms is required for pesticide registration in the European Union (COUNCIL OF THE EUROPEAN COMMUNITIES, 1991; COUNCIL OF THE EUROPEAN COMMUNITIES, 1996). Selectivity towards the natural enemies of pests has already known for many registered insecticides. According to Commission Directive 96/12/EC (COUNCIL OF THE EUROPEAN COMMUNITIES, 1996), two standard pesticidesensitive species, a parasitoid and a predatory mite (e.g., Aphidius rhopalosiphi DeStefani, 1902 and Typhlodromus pyri Scheuten, 1857), should be used in tests of insecticide side effects on arthropods. Only two additional species that are relevant to the intended use of the substance should also been tested. Therefore, knowledge about the selectivity of insecticides is usually incomplete.

Some insecticides are not entirely selective towards some beneficial species, e.g., acetamiprid was moderately harmful to Chrysoperla carnea larvae (Nasreen et al., 2005), and residues of acetamiprid and abamectin had moderate to high toxicity to hatched larvae of Deraeocoris brevis (Uhler, 1904) (Dong-Soon et al., 2006). The toxicity of insecticides can greatly differ for particular developmental stages of beneficial organisms, e.g., deltamethrin is harmless to the eggs of $C$. carnea (Giolo et al., 2009) and slightly harmful (Garzon et al., 2015) or moderately harmful (Maia et al., 2016) to the larvae of $C$. carnea. In addition, data for some insecticides obtained by different authors are inconsistent, e.g., abamectin has been assessed as harmless for $C$. carnea larvae by Bueno and Freitas (2004) but slightly harmful by Maia et al. (2016). Usually, only data about the side effects on a single developmental stage are available for particular species of natural enemies. Limited data are available about the side effects of biopesticides.

Chrysoperla carnea is present in a wide range of agricultural crops and is one of the most commonly used and commercially available natural enemies (Tauber et al., 2000). Chrysoperla carnea consumes a wide range of arthropods, such as aphids, scales, leafhoppers, whiteflies, psyllids, thrips, eggs and larvae of lepidopterans, and mites (Principi and Canard, 1984).

Forficula auricularia is the most common species from the order Dermaptera in the Czech Republic (Kočárek et al., 2005). Adults and larvae are important predators of many arthropods (e.g., Lepidoptera, Homoptera, Diptera). Earwigs also consume plant material and, for this reason, they can be sometimes classified as pest (Solomon et al., 2000).

Adalia bipunctata (Coleoptera: Coccinellidae) is commercially available and widely used to protect horticultural crops (Robledo Camacho et al., 2009). It consumes aphids and, together with other coccinellids, contributes to decreased population growth rates of aphids (Hodek and Honěk, 1996).

Harmonia axyridis (Coleoptera: Coccinellidae) was widely introduced as a biological control agent of aphids and coccids. On the other hand, this invasive alien ladybird in Europe has a negative effect on some native coccinelid species (Brown et al., 2008). The first occurrence of the species in the Czech Republic was documented in 2006 (Špryňar, 2008), and after a short period, it became a dominant species in some habitats (Honěk et al., 2016).

Harmonia axyridis and Coccinella septempunctata are the most important predators of aphids in orchards and hop gardens as well as Cacopsylla spp. (Hemiptera: Psyllidae) in pear orchards in the Czech Republic. Large populations of both species could reduce the number of insecticide treatments against these pests (1-2 per season). Forficula auricularia is a locally important predator of aphids and Cacopsylla spp.; nevertheless, its population density in orchards has decreased in the past 20-30 years, most likely due to new active substances registered for use in orchards. Added shelters on trees usually have no significant positive effect on F. auricularia populations. Chrysoperla carnea is common in all agricultural crops; nevertheless, the species population size is typically low, and it is only a complementary predator in the system (Holý and Stará, unpublished results). Populations of A. bipunctata have decreased since the 1980s (Honěk et al., 2016), and adults and larvae are rare in orchards and hop gardens.

The goal of the present study was to characterize the side effects of some pesticides and biopesticides used for pest control in orchards, hop gardens and field vegetables on selected natural enemy species and to prove the suitability of the tested pesticides for use in integrated pest management programmes. Pesticide selections were made on the basis of 
frequency of use in target crops in the Czech Republic and the knowledge of their side effects (whether they were not tested yet or if different published results contained contradictory information). We focused mainly on biopesticides and fungicides, which are less frequently tested. Twelve insecticides, 11 fungicides and 8 biopesticides registered in the Czech Republic were selected to test their effects on eggs and larvae of Chrysoperla carnea (Stephens, 1836) (Neuroptera: Chrysopidae), adults of Forficula auricularia (Linnaeus, 1758) (Dermaptera: Forficulidae), larvae of Adalia bipunctata (Linnaeus, 1758) (Coleoptera: Coccinellidae) and adults of Harmonia axyridis (Pallas, 1773) (Coleoptera: Coccinellidae).

\section{MATERIALS AND METHODS}

\section{Insecticides}

In total, 31 commercial formulations of insecticides, fungicides and biopesticides were tested against selected predators. The pesticides were diluted in distilled water in the concentrations recommended on the product labels, and Break-Thru SPU surfactant based on polyether-polymethylsiloxane-copolymer 80\% and polyether 20\% (Goldschmidt AG, Essen, Germany) in concentration 0.05\% was added when appropriate (Tab. I). The Quassia amara L. extract was prepared 2-4 h before application by boiling Quassia wood chips (100 g) in 21 of water for one hour (Psota et al., 2010). The insecticides tested against particular species were selected according to the available data about their selectivity against the tested species.

\section{Insects}

Chrysoperla carnea larvae originated from Koppert B. V. (Berkel en Rodenrijs, The Netherlands). The larvae (second instar) were mixed with buckwheat in $500 \mathrm{ml}$ bottles. Chrysoperla carnea eggs originated from the laboratory colony of $C$. carnea maintained in the Institute of Entomology, Biology Centre CAS (České Budějovice, the Czech Republic). The eggs were on office paper.

Forficula auricularia adults were collected from paper belt traps placed on tree trunks in the experimental apple orchard of the Crop Research Institute, Prague, the Czech Republic. The earwigs were in groups of 20 and placed in $100 \mathrm{ml}$ plastic cups. To minimize the stress of earwigs, pieces of grass were in cups as a shelter. The plastic cups with earwigs were transported in a styrofoam box to the laboratory. Earwigs were stored in a refrigerator at $5^{\circ} \mathrm{C}$ for $24 \mathrm{~h}$.

Adalia bipunctata larvae originated from Koppert B. V. (Berkel en Rodenrijs, The Netherlands). The larvae (first instar) were with buckwheat in cotton bags. Eggs of Sitotroga cerealella (Olivier, 1789) were as food to avoid starvation during transport.

The Harmonia axyridis used in the test procedures originated from adults collected in an apple orchard in Bílé Podolí, the Czech Republic. Adults were collected in groups of 20 into $100 \mathrm{ml}$ plastic cups. To minimize stress, pieces of grass were in the cups as a shelter. The plastic cups with $H$. axyridis were transported in a styrofoam box to the laboratory. Adults fed aphids and were stored at $20^{\circ} \mathrm{C}$ for $24 \mathrm{~h}$.

\section{Test Procedures}

The larvae of $C$. carnea were placed in groups of ten onto wet filter paper in $100 \mathrm{ml}$ plastic cups with a perforated lid and incubated in the refrigerator at $5{ }^{\circ} \mathrm{C}$ for $6 \mathrm{~h}$ before the experiment. After incubation, the larvae were placed at $20{ }^{\circ} \mathrm{C}$ for $0.5 \mathrm{~h}$, and only larvae with good fitness (moving in the cups) were selected for use in the experiment. The side effects of the insecticides against larvae of $C$. carnea were tested using a bioassay on filter paper $(125 \times 83 \mathrm{~mm})$ treated with insecticides. The insecticide solutions were applied to filter paper by using an SG e1 hand sprayer (Biostep; Germany). The sprayed volume was $0.52 \pm 0.1 \mathrm{ml}$ per filter paper. The filter paper in the control group was treated with distilled water with Break-Thru 0.05\%. After application, the filter papers were placed into the culture wares and stored in the laboratory for $1 \mathrm{~h}$ to dry. Larvae of $C$. carnea were introduced individually into a 24-well tissue culture ware (IWAKI \& CO., Ltd., Tokyo, Japan), and the wells were closed with treated filter paper. The wares were turned upside down to enable contact of larvae with the filter paper. Chrysoperla carnea larvae (groups of ten per replication) were exposed to fresh insecticide residues for $24 \mathrm{~h}$ and incubated in a climatic chamber at $22{ }^{\circ} \mathrm{C}, 65 \%$ relative humidity and a photoperiod of $16 \mathrm{~L}: 8 \mathrm{D}$ h. Four replications were performed per treatment. After a period of $24 \mathrm{~h}$, mortality was evaluated. The experiment was carried out without feeding the larvae.

A similar method as for larvae of $C$. carnea was used for larvae of $A$. bipunctata. The difference was in use of polypropylene (PP) autoclavable boxes with 50 places (File Cases for Micro Vials, Cat. No. 2-1535, NeoLab, Germany). The size of the filter paper was $140 \times 70 \mathrm{~mm}$, and the spray volume was $0.49 \pm 0.1 \mathrm{ml}$ per filter paper. The mortality was evaluated after $12 \mathrm{~h}$.

The side effect of insecticides on $C$. carnea eggs were tested using a dip test. Chrysoperla carnea eggs (groups of ten per replication) laid on a piece of office paper were dipped for $5 \mathrm{~s}$ into a solution of pesticide in a $100 \mathrm{ml}$ beaker. Four replications were performed per treatment. After the treatment, the eggs were placed on filter paper to dry. The dried eggs were placed into $250 \mathrm{ml}$ plastic cups with a perforated lid and wet filter paper at the bottom and incubated in a climatic chamber at $22{ }^{\circ} \mathrm{C}, 65 \%$ relative humidity and a photoperiod of $16 \mathrm{~L}: 8 \mathrm{D}$ h. Evaluations of egg mortality were performed after hatching all the eggs, i.e., after a week since the first eggs hatched. 
I: The trade names, active ingredients, companies and concentrations of pesticides used in the study

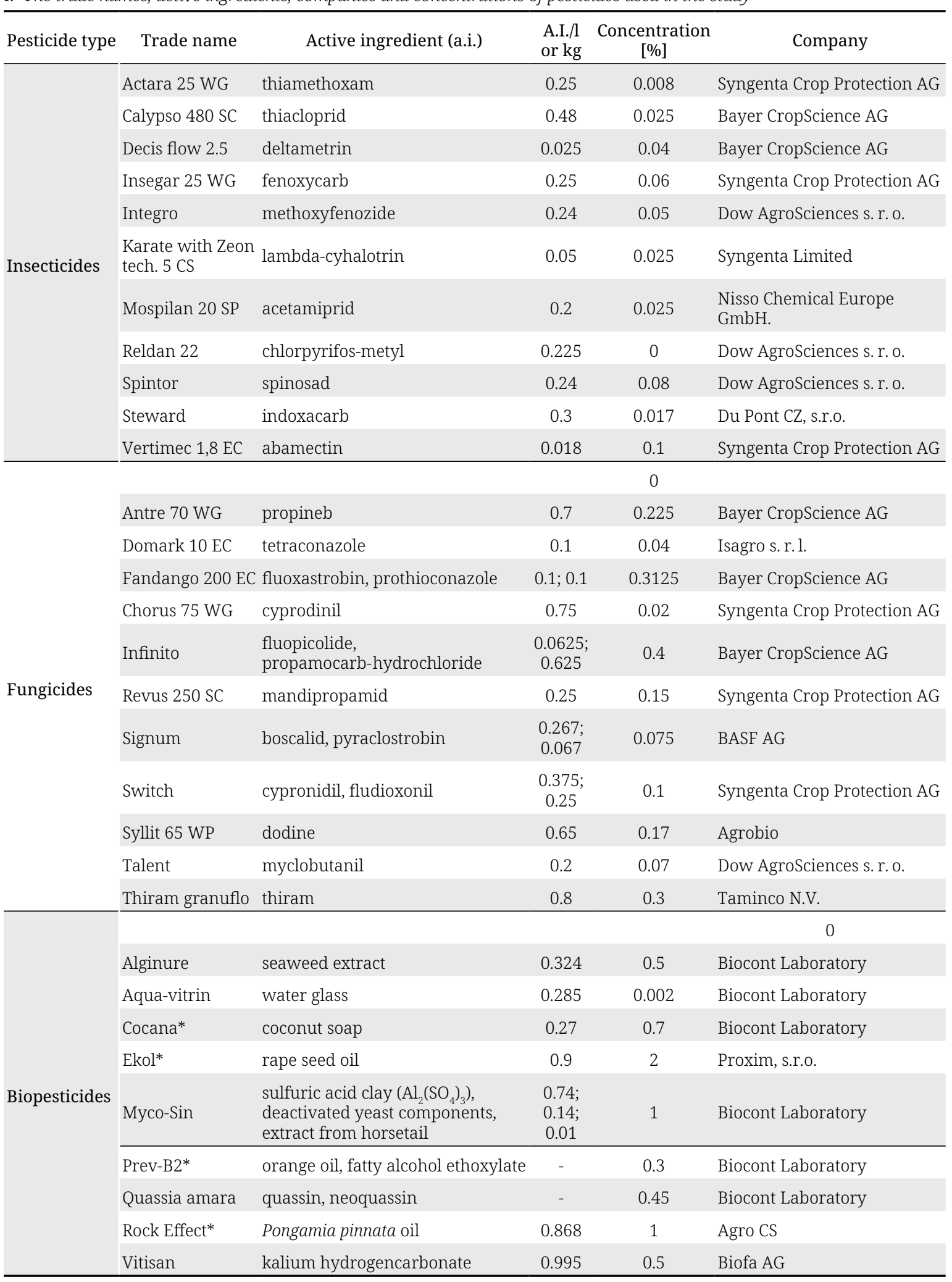

Products marked with * were used without Break-Thru addition (concentration 0.05\%)

A topical application bioassay was used to test the side effect of insecticides on $F$. auricularia adults. Before the experiment, earwigs were sorted into groups of 10 into $100 \mathrm{ml}$ plastic cups with perforated lids and dry filter paper at the bottom. Pieces of apples were provided as food for the duration of the 
experiment. The earwigs were inhibited by $\mathrm{CO}_{2}$, and a 1- $\mu \mathrm{l}$ volume of pesticide dissolved in acetone was applied topically to each earwig with a Multipette Plus dispenser (Eppendorf AG, Hamburg, Germany). Pure acetone was used in the control variant. No Break-Thru surfactant was used in this experiment. The treated earwigs in plastic cups were incubated in a climatic chamber at $22{ }^{\circ} \mathrm{C}, 65 \%$ relative humidity and a photoperiod of $16 \mathrm{~L}: 8 \mathrm{D} \mathrm{h}$. After a period of $48 \mathrm{~h}$, the mortality of earwigs was evaluated.

Harmonia axyridis adults were sorted into groups of 10 into $100 \mathrm{ml}$ plastic cups $(90 \times 50 \mathrm{~mm})$ with perforated lids and dry filter paper at the bottom. Each cup was treated with $0.32 \pm 0.1 \mathrm{ml}$ of solution sprayed as a mist over the beetle (Smith and Kirschik, 2000) by using an SG e1 hand sprayer (Biostep, Germany). The treated coccinelids in the plastic cups were incubated in a climatic chamber at $22{ }^{\circ} \mathrm{C}, 65 \%$ relative humidity and a photoperiod of $16 \mathrm{~L}: 8 \mathrm{D}$ h. After a period of 24 and $48 \mathrm{~h}$, the mortality of adults was evaluated. The experiment was carried out without feeding adults. Only insects that had good fitness were used for the bioassays.

\section{Statistical Analysis}

The data of $C$. carnea eggs, F. auricularia adults, A. bipunctata larvae and $H$. axyridis adults, presented as the mean of mortality $\pm \mathrm{SD}$, were analysed using one-way analysis of variance (ANOVA) after testing their normality with a Shapiro-Wilk test using the XLSTAT 2015 statistical software package (Addinsoft Inc., New York, USA). The means were separated using Tukey's HSD analysis. The data for the $C$. carnea larval mortality did not follow a normal distribution and were analysed using the nonparametric Kruskal-Wallis test following the multiple pairwise comparisons using the SteelDwass-Critchlow-Fligner procedure. The mortality data corrected using Abbott (1925) are presented in tables. According to the IOBC laboratory scale (Hassan, 1994) and the mortalities corrected by the control mortality (Abbott, 1925), the pesticides were classified into four toxicity categories:

1. harmless (<30\%);

2. slightly harmful (30-79\%);

3. moderately harmful (80-99\%); and

4. harmful (> 99\%).

\section{RESULTS}

\section{Lethal Effects of Insecticides on Chrysoperla carnea Mortality}

According to the results of ANOVA model, differences in the mortality of $C$. carnea eggs were found after $24 \mathrm{~h}(\mathrm{~F}=4.476, \mathrm{df}=6,21, \mathrm{p}=0.005)$ of exposure to residues of insecticides (Tab. II). The mortality in the control group reached $15.5 \%$ of $C$. carnea eggs. Most of the tested insecticides were harmless to $C$. carnea eggs, causing corrected mortality from 0\% (chlorpyrifos-

II: Pesticide side effects on Chrysoperla carnea eggs and placement into IOBC side-effect classes. Values with different small letters are significantly different.

\begin{tabular}{lccccc}
\hline \multicolumn{1}{c}{ Pesticide } & $\mathrm{N}$ & Emerged larvae & $*$ Mortality of eggs \% & sd & \multicolumn{2}{c}{ IOBC class } \\
\hline Reldan 22 & 40 & 36 & $0^{\mathrm{a}}$ & 0 & 1 \\
Decis Flow 2.5 EC & 44 & 41 & $0^{\mathrm{a}}$ & 0 & 1 \\
Steward & 56 & 36 & $18.8^{\mathrm{ab}}$ & 21.5 & 1 \\
Mospilan 20 SP & 47 & 31 & $21.4^{\mathrm{ab}}$ & 7.00 & 1 \\
Spintor & 52 & 33 & $24.1^{\mathrm{ab}}$ & 17.9 & 1 \\
Integro & 42 & 23 & $32.0^{\mathrm{b}}$ & 22.1 & 2 \\
\hline
\end{tabular}

*corrected mortality by Abbott

$\mathrm{sd}=$ standard deviation

III: Pesticide side effects on Chrysoperla carnea larvae and placement into IOBC side-effect classes. Values with different small letters are significantly different.

\begin{tabular}{llcccc}
\hline \multicolumn{1}{c}{ Pesticide } & $\mathrm{N}$ & Dead larvae during $1^{\text {st }}$ moulting & $*$ Mortality $\%$ & sd & IOBC class \\
\hline Alginure & 40 & 0 & $0^{\mathrm{a}}$ & 0 & 1 \\
Aqua-vitrin & 40 & 1 & $2.5^{\mathrm{a}}$ & 5.0 & 1 \\
Myco-Sin & 40 & 0 & $0^{\mathrm{a}}$ & 0 & 1 \\
Prev-B2 & 40 & 0 & $0^{\mathrm{a}}$ & 0 & 1 \\
Rock effect & 40 & 0 & $0^{\mathrm{a}}$ & 0 & 1 \\
Vitisan & 40 & 0 & $0^{\mathrm{a}}$ & 0 & 1 \\
\hline
\end{tabular}

*corrected mortality by Abbott

sd = standard deviation 
methyl and deltamethrin) to 24.1\% (spinosad) $24 \mathrm{~h}$ after application (Tab. II). Methoxyfenozide was slightly harmful, causing 32.0\% corrected mortality of $C$. carnea eggs after $24 \mathrm{~h}$.

According to results of the Kruskal-Wallis test, no significant differences in the mortality of $C$. carnea larvae were found after $24 \mathrm{~h}\left(\mathrm{KW}-\mathrm{H}_{6,4}=6, \mathrm{a}=0.05\right.$, $\mathrm{p}=0.423$ ) of exposure to dry biopesticide residues (Tab. III). No mortality was recorded in the control variant. All of the tested biopesticides were harmless to $C$. carnea larvae. Except for water glass, which causes a $2.50 \%$ mortality of $C$. carnea larvae, all of the tested biopesticides caused no mortality of $C$. carnea larvae (Tab. III).

\section{Side Effects of Insecticides on Forficula auricularia Mortality}

The ANOVA model showed differences in the mortality of F. auricularia adults after $48 \mathrm{~h}$ $(\mathrm{F}=148.438$, df $=15,49, \mathrm{p}<0.0001)$ from the application of synthetic pesticides and biopesticides (Tab. IV). The mortality in the control group reached $1.1 \%$. All of the tested synthetic fungicides and biopesticides were harmless to F. auricularia adults, causing mortality from $0 \%$ to $1.38 \%$ (seaweed extract) $48 \mathrm{~h}$ after application (Tab. IV). Chlorpyrifosmethyl was slightly harmful, causing $57.5 \%$ mortality of $F$. auricularia adults after $48 \mathrm{~h}$. The rest of the tested synthetic insecticides were harmless, causing no mortality of $F$. auricularia adults (Tab. IV). Chlorpyrifos-methyl caused 57.5\% mortality, but the rest of the surviving individuals showed dramatically changed behaviour with reduced mobility. Similar behavioural changes were observed in dodine and thiacloprid variants.

\section{Side Effects of Insecticides on Adalia bipunctata Mortality}

The ANOVA results showed large differences in the sensitivity of $A$. bipunctata larvae to the tested synthetic pesticides and biopesticides. The mortality of $A$. bipunctata larvae differed significantly after $24 \mathrm{~h}$ of application of the tested pesticides ( $\mathrm{F}=29.125$, $\mathrm{df}=14,30, \mathrm{p}<0.0001)$ (Tab. V). The mortality in the control variant reached $16.7 \%$. Most of the tested biopesticides were harmless to Adalia bipunctata larvae, causing corrected mortality values from $0 \%$ (hydrogencarbonate) to $16.0 \%$ (sulfuric acid clay $\left(\mathrm{Al}_{2}\left(\mathrm{SO}_{4}\right)_{3}\right)$, deactivated yeast components, extract from horsetail). The toxic effect of the tested synthetic fungicides varied from harmless to moderately harmful to A. bipunctata larvae, causing mortality from $20.0 \%$ (boscalid + pyraclostrobin in Signum) to $92.0 \%$ (myclobutanil). However, most of the tested synthetic fungicides were slightly harmful to $A$. bipunctata larvae. The tested neonicotinoids acetamiprid and thiacloprid were moderately harmful and harmful, respectively, to A. bipunctata larvae, causing mortality rates of $88.0 \%$ and $100 \%$ (Tab. V).

\section{Side Effects of Insecticides on Harmonia axyridis Mortality}

The ANOVA results showed significant differences in the mortality of $H$. axyridis adults $24 \mathrm{~h}$ after the application of tested synthetic pesticides and biopesticides $(\mathrm{F}=271.251$, $\mathrm{df}=20,63, \mathrm{p}<0.0001)$ (Tab. VI). No mortality was observed in the control variant. All the tested biopesticides and synthetic fungicides were harmless to $H$. axyridis adults, causing mortality from $0 \%$ to $7.50 \%$ (coconut soap and propineb). Large differences in toxicity

IV: Pesticide side effects on Forficula auricularia adults and placement into IOBC side-effect classes. Values with different small letters are significantly different.

\begin{tabular}{llcccc}
\hline \multicolumn{1}{c}{ Pesticide } & $\mathrm{N}$ & Dead adults & *Mortality of adults $\%$ & sd & IOBC class \\
\hline Alginure & 72 & 1 & $1.38 \mathrm{a}$ & 3.67 & 1 \\
Vitisan & 80 & 1 & $1.25 \mathrm{a}$ & 3.31 & 0 \\
Calypso 480 SC & 41 & 0 & $0 \mathrm{a}$ & 0 & $1^{* *}$ \\
Insegar 25 WG & 42 & 0 & $0 \mathrm{a}$ & 0 & 1 \\
Mospilan 20 SP & 30 & 0 & $0 \mathrm{a}$ & 0 & 1 \\
Mycosin & 78 & 0 & $0 \mathrm{a}$ & 0 & 1 \\
Quassia amara & 30 & 0 & $0 \mathrm{a}$ & 0 & 1 \\
Rock Effect & 39 & 0 & $0 \mathrm{a}$ & 0 & 1 \\
Syllit 65 WP & 40 & 0 & $0 \mathrm{a}$ & 0 & 1 \\
Thiram granuflo & 30 & 0 & $0 \mathrm{a}$ & 0 & 1 \\
Vertimec 1.8 EC & 41 & 0 & $0 \mathrm{a}$ & 4.33 & 1 \\
Reldan 22 & 40 & 23 & $57.5 \mathrm{~b}$ & $2^{* *}$ \\
\hline
\end{tabular}

*corrected mortality by Abbott

** effect on behaviour

$\mathrm{sd}=$ standard deviation 
V: Pesticide side effects on Adalia bipunctata larvae and placement into IOBC side-effect classes. Values with different small letters are significantly different.

\begin{tabular}{llcccc}
\hline \multicolumn{1}{c}{ Pesticide } & $\mathrm{N}$ & Dead larvae during $1^{\text {st }}$ molting & $*^{2}$ Mortality $\%$ & sd & IOBC class \\
\hline Vitisan & 30 & 4 & $0^{\mathrm{a}}$ & 6.93 & 1 \\
Alginure & 30 & 7 & $7.96^{\mathrm{ab}}$ & 6.93 & 1 \\
Prev-B2 & 30 & 8 & $12.0^{\mathrm{ab}}$ & 6.93 & 1 \\
Myco-Sin & 30 & 9 & $16.0^{\mathrm{ab}}$ & 20.8 & 1 \\
Signum & 30 & 10 & $20.0^{\mathrm{ab}}$ & 18.3 & 1 \\
Cocana & 30 & 13 & $32.0^{\mathrm{bc}}$ & 13.9 & 2 \\
Chorus 75 WG & 30 & 20 & $56.0^{\text {cd }}$ & 6.93 & 2 \\
Fandango 200 EC & 30 & 21 & $60.0^{\text {cde }}$ & 18.3 & 2 \\
Infinito & 30 & 21 & $64.0^{\text {cde }}$ & 12.0 & 2 \\
Revus 250 SC & 30 & 23 & $64.0^{\text {cde }}$ & 12.0 & 2 \\
Switch & 30 & 27 & $72.0^{\text {def }}$ & 6.93 & 2 \\
Mospilan 20 SP & 30 & 28 & $88.0^{\text {def }}$ & 0 & 3 \\
Talent & 30 & 30 & $92.0^{\text {ef }}$ & 6.93 & 3 \\
Calypso 480 SC & 30 & $100^{\mathrm{f}}$ & 0 & 4 \\
\hline
\end{tabular}

*corrected mortality by Abbott

sd = standard deviation

VI: Pesticide side effects on Harmonia axyridis adults and placement into IOBC side-effect classes. Values with different small letters are significantly different.

\begin{tabular}{llcccc}
\hline \multicolumn{1}{c}{ Pesticide } & $\mathrm{N}$ & dead adults & $*$ mortality $\%$ & sd & IOBC class \\
\hline Alginure & 40 & 0 & $0 \mathrm{a}$ & 0 & 1 \\
Chorus 75 WG & 40 & 0 & $0 \mathrm{a}$ & 0 & 1 \\
Ekol & 40 & 0 & $0 \mathrm{a}$ & 0 & 1 \\
Infinito & 40 & 0 & $0 \mathrm{a}$ & 0 & 1 \\
Myco-Sin & 40 & 0 & $0 \mathrm{a}$ & 0 & 1 \\
Prev-B2 & 40 & 0 & $0 \mathrm{a}$ & 0 & 1 \\
Revus 250 SC & 40 & 0 & $0 \mathrm{a}$ & 0 & 1 \\
Swich & 40 & 0 & $0 \mathrm{a}$ & 0 & 1 \\
Talent & 40 & 0 & $0 \mathrm{a}$ & 0 & 1 \\
Vitisan & 40 & 0 & $0 \mathrm{a}$ & 0 & 1 \\
Fandango 200 EC & 40 & 1 & $2.50 \mathrm{a}$ & 4.33 & 1 \\
Signum & 40 & 1 & $2.50 \mathrm{a}$ & 4.33 & 1 \\
Domark 10 EC & 40 & $2.50 \mathrm{a}$ & 4.33 & 1 \\
Cocana & 40 & 3 & $7.50 \mathrm{a}$ & 8.29 & 1 \\
Antre 70 WG & 40 & 3 & $7.50 \mathrm{a}$ & 8.29 & 1 \\
Actara 25 WG & 40 & 40 & $30.0 \mathrm{~b}$ & 7.07 & 2 \\
Calypso 480 SC & 40 & 40 & $100 \mathrm{c}$ & 0 & 4 \\
Karate with Zeon technol. & 40 & 40 & 0 & 0 \\
Mospilan 20 SP & 40 & 0 & & 4 \\
\hline
\end{tabular}

*corrected mortality by Abbott $\mathrm{sd}=$ standard deviation 
were obtained for the tested neonicotinoids. Thiamethoxam was slightly harmful, with 30.0\% mortality of $H$. axyridis, while thiacloprid and acetamiprid were harmful, causing 100\% mortality. The organophosphate chlorpyrifos-methyl was also harmful, causing $100 \%$ mortality of $H$. axyridis adults (Tab. VI)

\section{DISCUSSION}

The success of IPM and organic regimes is closely connected with the survival of beneficial organisms in the environment. Beneficials are more important in organic regimes due to the low number of available insecticides. More knowledge is known about the side effects of synthetic insecticides than those of biopesticides and fungicides. Nevertheless, biopesticides could also have negative effects on beneficials. Hence, complete information on the selectivity and possible side effects of pesticides, especially newly registered ones, is necessary to maintain an IPM and organic regime functional in particular crops.

Among the insecticides tested against the four species C. carnea, F. auricularia, A. bipunctata and $H$. axyridis, the neonicotinoids thiacloprid and acetamiprid had diverse effects ranging from harmless against $C$. carnea larvae to harmful against $H$. axyridis adults. There was great diversity in the toxicity of acetamiprid according to species, ranging from the harmless effect on Neoseiulus cucumeris to the harmful effect on Aphidius colemani, was also found in our previous work (Stará et al., 2014). Thiacloprid does not kill $F$. auricularia adults, but it does have a negative effect on their mobility. Negative behavioural changes were observed also in the adults who survived the chlorpyrifos-methyl variant. Thiamethoxam was the least toxic neonicotinoid from the three neonicotinoids tested and was only slightly harmful to the adults of $H$. axyridis. Similar results were obtained by Galvan et al. (2006).

Most of the tested fungicides were harmless to $H$. axyridis adults and $F$. auricularia adults, except dodine, which caused no mortality of $F$. auricularia but same as thiacloprid had negative effect on behavioural changes of all adults. In all cases, larvae of $A$. bipunctata were more sensitive to tested fungicides than $H$. axyridis adults. Most of the tested fungicides were slightly harmful to A. bipunctata. Large differences in the toxicities of substances against the developmental stages of tested Coccinellidae were found for myclobutanil, which was harmless to $H$. axyridis larvae but moderately harmful to A. bipunctata larvae. Regarding the wide range of mortality (30-79\%) in toxicity category 2 , which is slightly harmful according to the IOBC laboratory scale, the use of fungicides in the period of presence of Coccinellidae larvae in orchards should be carefully considered.

All of the tested biopesticides were harmless to C. carnea larvae, F. auricularia adults and $H$. axyridis adults. Again, $A$. bipunctata larvae proved to be less tolerant than $H$. axyridis adults, e.g., in the case of Cocana (coconut soap) and Myco-sin (sulfuric acid clay $\left(\mathrm{Al}_{2}\left(\mathrm{SO}_{4}\right)_{3}\right)$, deactivated yeast components, extract from horsetail).

In general, the $1^{\text {st }}$ instar larvae of $A$. bipunctata were the most sensitive to the tested pesticides, which corresponds with Olszak (1999), while F. auricularia adults and both tested stages of C. carnea were tolerant. According to Medina et al. (2008), C. carnea is considered relatively tolerant to pesticides, but the larvae are more susceptible than adults (Giolo et al., 2009). In our experiment, eggs of C. carnea were tolerant to all of the tested insecticides, including acetamiprid, which was slightly harmful and harmful to $A$. bipunctata and $H$. axyridis, respectively. Similarly, $C$. carnea eggs were tolerant to deltamethrin, while lambda-cyhalothrin, which is from the same class II of pyrethroids, was harmful to $H$. axyridis adults. Spinosad was harmless to $C$. carnea eggs in our experiment but was slightly harmful to A. aphidimyza and N. cucumeris and harmful to A. colemani (Stará et al., 2011).

\section{CONCLUSION}

The tested biopesticides had no negative effects on Chrysoperla carnea, Forficula auricularia, Adalia bipunctata and Harmonia axyridis. The synthetic fungicides were harmless or only slightly harmful to the tested natural enemies. Forficula auricularia adults and both tested stages of $C$. carnea were tolerant to the tested pesticides. In general, A. bipunctata larvae were more sensitive to the tested pesticides than $H$. axyridis adults. Both $A$. bipunctata larvae and $H$. axyridis adults were sensitive to the tested neonicotinoids.

From a practical point of view, only the pesticides that were classified as harmless or slightly harmful can be considered suitable for use in integrated or organic regimes. In fact, a mortality of beneficial species higher than $80 \%$ is too high to enable the beneficial species to alter the dynamics of pest populations. Hence, moderately harmful pesticides do not differ from the pesticides that were classified as harmful regarding their real impact on beneficial species. Our results bring other information to the mosaic of knowledge of the side effects of pesticides and could be used for improving IPM and organic regimes in different crops. 
Acknowledgements

This work was supported by the Ministry of Agriculture of the Czech Republic, institutional support No. MZE-RO0418 and project No. QK1710200.

\section{REFERENCES}

ABBOTT, W. S. 1925. A method of computing the effectiveness of the insecticide. Journal of Economic Entomology, 18(2): 265-267.

COUNCIL OF THE EUROPEAN COMMUNITIES. 1991. Council Directive 91/414/EEC of 15 July 1991 concerning the placing of plant protection products on the market. Official Journal of the European Communities, 34: L 230.

COUNCIL OF THE EUROPEAN COMMUNITIES. 1996. Commission Directive 96/12/EC of 8 March 1996 amending Council Directive 91/414/EEC concerning the placing of plant protection products on the market. Official Journal of the European Communities, 39: L 65.

AMARASEKARE, K. G. and SHEARER, P. W. 2017. Stability of Cacopsylla pyricola (Hemiptera: Psyllidae) Populations in Pacific Northwest Pear Orchards Managed with Long-Term Mating Disruption for Cydia pomonella (Lepidoptera: Tortricidae). Insects, 8(4): 105.

BROWN, P. M. J., ADRIAENS, T., BATHON, H., CUPPEN, J., GOLDARAZENA, A., HAGG, T., KENIS, M., KLAUSNITZER, B. E. M., KOVAR, I., LOOMANS, A. J. M., MAJERUS, M. E. N., NEDVED, O., PEDERSEN, J., RABITSCH, W., ROY, H. E., TERNOIS, V., ZAKHAROV, I. A. and ROY, D. B. 2008. Harmonia axyridis in Europe: spread and distribution of a non-native Coccinellid. BioControl, 53: 5-21.

BUENO, A. F. and FREITAS, S. 2004. Effect of the insecticides abamectin and lufenuron on eggs and larvae of Chrysoperla externa under laboratory conditions. BioControl, 49: 277-283.

DONG-SOON, K., BROOKS, D. J. and RIEDL, H. 2006. Lethal and sublethal effects of abamectin, spinosad, methoxyfenozide and acetamiprid on the predaceous plant bug Deraeocoris brevis in the laboratory. BioControl, 51: 465-484.

EPSTEIN, D. L., ZACK, R. S., BRUNNER, J. F., GUT, L. and BROWN, J. J. 2000. Effects of broad-spectrum insecticides on epigeal arthropod biodiversity in Pacific Northwest apple orchards. Environmental Entomology, 29(2): 340-348.

GALLARDO, R. K., BRUNNER, J. F. and CASTAGNOLI, S. 2016. Capturing the economic value of biological control in western tree fruit. Biological Control, 102: 93-100.

GARZÓN, A., MEDINA, P., AMOR, F., VIÑUELA, E. and BUDIA, F. 2015. Toxicity and sublethal effects of six insecticides to last instar larvae and adults of the biocontrol agents Chrysoperla carnea (Stephens) (Neuroptera: Chrysopidae) and Adalia bipunctata (L.) (Coleoptera: Coccinellidae). Chemosphere, 132: 87-93.

GIOLO, F. P., MEDINA, P., GRÜTZMACHER, A. D. and VIÑUELA, E. 2009. Effects of pesticides commonly used in peach orchards in Brazil on predatory lacewing Chrysoperla carnea under laboratory conditions. BioControl, 54: 625-635.

HASSAN, S. A. 1994. Activities of the IOBC/WPRS working group pesticides and beneficial organisms. IOBC/WPRS Bulletin, 17: 1-5.

HODEK, I. and HONĚK, A. 1996. Ecology of Coccinellidae. Dordrecht: Kluwer Academic Publishers.

HONĚK, A., MARTÍNKOVÁ, Z., DIXON, A. F. G., ROY, H. E. and PEKÁR, S. 2016. Long-term changes in communities of native coccinellids: population fluctuations and the effect of competition from an invasive non-native species. Insect Conservation and Diversity, 9(3): 202-209.

KOČÁREK, P., HOLUŠA, J. and VIDLIČKA, L. 2005. Blattaria, Mantodea, Orthoptera \& Dermaptera of the Czech and Slovak Republics. Illustrated key 3. Zlín: Kabourek.

MAIA, J. B., CARVALHO, G. A., MEDINA, P., GARZÓN, A., GONTIJO, P. C. and VIÑUELA, E. 2016. Lethal and sublethal effects of pesticides on Chrysoperla carnea larvae (Neuroptera: Chrysopidae) and the influence of rainfastness in their degradation pattern over time. Ecotoxicology, 25(5): 845-855.

MEDINA, P., ADÁN, A., DEL ESTAL, P., BUDIA, F. and VIÑUELA, E. 2008. Integración del control biológico con otros métodos de control. In: JACAS, J. and URBANEJA, A. (Eds.). Control biológico de plagas agrícolas. Valencia: Phytoma España S. L.

MEISSLE, M., MOURON, P., MUSA, T., BIGLER, F., PONS, X., VASILEIADIS, V. P., OTTO, S., ANTICHI, D., KISS, J., PÁLINKÁS, Z., DORNER, Z., VAN DER WEIDE, R., GROTEN, J., CZEMBOR, E., ADAMCZYK, J., THIBORD, J. B., MELANDER, B. and OLDENBURG, E. 2010. Pests, pesticide use and alternative options in European maize production: current status and future prospects. Journal of Applied Entomology, 134: 357-375. 
MILICZKY, E. R., CALKINS, C. O. and HORTON, D. R. 2000. Spider abundance and diversity in apple orchards under three pest management programmes in Washington State, U.S.A. Agricultural and Forest Entomology, 2: 203-215.

NASREEN, A., GHULAM, M. and ASHFAQ, M. 2005. Mortality of Chrysoperla carnea (Stephens) (Neuroptera: Chrysopidae) after exposure to some insecticides; laboratory studies. South Pacific Studies, 26(1): 1-6.

OLSZAK, R. W. 1999. Influence of some pesticides on mortality and fecundity of the aphidophagous coccinellid Adalia bipunctata L. (Col., Coccinellidae). Journal of Applied Entomology, 123(1): 41-45.

PRINCIPI, M. M. and CANARD, M. 1984. Feeding habits. In: CANARD, M., SÉMÉRIA, Y. and NEW, T. R. (Eds.). Biology of Chrysopidae. Hague: Dr W. Junk Publishers.

PSOTA, V., OUREEDNÍČKOVÁ, J. and FALTA, V. 2010. Control of Hoplocampa testudinea using the extract from Quassia amara in organic apple growing. Horticultural Science, 37(4): 139-144.

ROBLEDO CAMACHO, A., VAN DER BLOM, J., SÁNCHEZ MARTÍNEZ, J. A. and TORRES JIMÉNEZ, S 2009. Control Biológico en Invernaderos Hortícolas. Almería: Coexphal.

SMITH, S. F. and KIRSCHIK, V. A. 2000. Effects of Biorational Pesticides on Four Coccinellid Species (Coleoptera: Coccinellidae) having Potential as Biological Control Agents in Interiorscapes. Journal of Economic Entomology, 93(3): 732-736.

SOLOMON, M. G., CROSS, J. V., FITZGERALD, J. D., CAMPBELL, C. A. M., JOLLY, R. L., OLSZAK, R. W., NIEMCZYK, E. and VOGT, H. 2000. Biocontrol of pests of apples and pears in northern and central Europe. 3. Predators. Biocontrol Science and Technology, 10(2): 91-128.

ŠPRYŇAR, P. 2008. Faunistic records from the Czech Republic - 252. Coleoptera: Coccinellidae. Klapalekiana, 44(1-2): 77-79.

STARÁ, J., OUŘEDNÍČKOVÁ, J. and KOCOUREK, F. 2011. Laboratory evaluation of the side effects of insecticides on Aphidius colemani (Hymenoptera: Aphidiidae), Aphidoletes aphidimyza (Diptera: Cecidomyiidae), and Neoseiulus cucumeris (Acari: Phytoseidae). Journal of Pest Science, 84: 25-31.

TAUBER, M. J., TAUBER, C. A., DANNE, K. M. and HAGEN, K. S. 2000. Commercialization of predators: recent lessons from green lacewings (Neuroptera: Chrysopidae: Chrysoperla). American Entomologist, 46(1): 26-38.

WESTIGARD, P. H. 1973. Pest status of insects and mites on pear in southern Oregon. Journal of Economic Entomology, 66(1): 227-232. 